\title{
LAS RUSALKI: ¿NINFAS ESLAVAS DE LAS AGUAS?
}

\section{FRANCISCO MOLINA MORENO}

Kobzar3@yahoo.com

Article received on 31.01.2014

Accepted on 07.07.2014

\section{RESUMEN}

El objeto de este trabajo es estudiar el hábitat de las rusalki, según fuentes de la tradición oral eslava oriental en los siglos XX y XXI. A través de una selección representativa de dichas fuentes, que ofrecemos traducidas al español, veremos cómo, en algunas regiones de Rusia, Ucrania y Bielorrusia, todavía se cree que el hábitat de las rusalki varía según la época del año o las horas del día. Dicha variación, que ya se atestiguaba en fuentes más antiguas, constituye una importante diferencia entre las rusalki y las ninfas, a pesar de que, según los primeros estudiosos de la mitología eslava, las rusalki eran las ninfas eslavas.

\section{PALABRAS CLAVE}

Mitología eslava, mitología clásica, espíritus acuáticos, rusalki, ninfas.

\section{ARE THE RUSALKI THE SLAVIC WATER NYMPHS?}

\section{ABSTRACT}

In this paper we shall deal with the habitat of the 'rusalki', according to contemporary sources of Eastern Slavic oral tradition. Through a selection of such sources, which we offer translated into Spanish, we shall see how in certain regions of Russia, Ukraine, and Byelorussia, it is still believed that the places where the 'rusalki' can be seen vary according to the seasons and even the hours of the day. This variation, already attested in earlier sources, makes an important difference among 'rusalki' and nymphs, although the first scholars dealing with Slavic mythology tried to define the 'rusalki' as Slavic nymphs.

\section{KEYWORDS}

Slavic mythology, Classical mythology, water spirits, rusalki, nymphs. 


\section{INTRODUCCIÓN ${ }^{1}$}

\subsection{Personajes que constituyen el objeto de este estudio}

Las rusalki (plural de rusalka ${ }^{2}$ ) son personajes femeninos del folklore ruso, ucraniano y bielorruso, que comparten algunas características con las ninfas y con las sirenas de la mitología clásica, y que aparecen en la semana siguiente o anterior a la Trinidad (siete semanas después de Pascua de Resurrección), en los campos de cereal, en los bosques y junto al agua, en forma de mujer de largos cabellos sueltos que puede ahogar en el agua o hacer cosquillas a las personas hasta matarlas. Tales son los rasgos de las rusalki que se atestiguan de forma más recurrente en Rusia, Ucrania y Bielorrusia (Molina Moreno 2012: 1-2; cf. Виноградова 2009б: 495).

El punto de partida de este trabajo está en el hecho de que los primeros estudiosos de la mitología eslava, para definir a las rusalki, se valían de la afinidad con las ninfas de las antiguas Grecia y Roma. Dicha afinidad era solo sugerida a manera de ejemplo, sin que ninguno de aquellos autores estudiara en detalle las similitudes y diferencias entre rusalki y ninfas; según las fuentes

1 En este trabajo presentamos parte de los resultados de un proyecto de investigación cofinanciado por el Ministerio de Ciencia e Innovación, la Universidad Complutense de Madrid y la Unión Europea, en el marco del programa "Ramón y Cajal” (RYC-2008-02327). Publicado con permiso del vicerrector de investigación de la Universidad Complutense de Madrid, D. José Francisco Tirado Fernández (carta del 29 de enero de 2014).

2 Para la transliteración de las palabras en ruso, ucraniano y bielorruso (salvo en los topónimos "Carelia", "Moscú" y "Siberia", en los que hemos conservado la forma habitual en español), empleamos el sistema propuesto por Alvarado Socastro 2003: 63 y 27-9; por nuestra parte, indicamos el acento gráfico según la norma española. Para facilitar la lectura a nuestros lectores no eslavistas, indicamos a continuación las correspondencias entre los caracteres cirílicos, la transliteración al alfabeto latino propuesta por Alvarado Socastro y la transcripción fonética según el alfabeto fonético internacional:

1. Ruso: $\mathrm{a}=\mathrm{a}=/ \mathrm{a} / ; \sigma=\mathrm{b}=/ \mathrm{b} / ; \mathrm{в}=\mathrm{v}=/ \mathrm{v} / ; \mathrm{r}=\mathrm{g}=/ \mathrm{g} /($ también ante $« \mathrm{e}, \mathrm{i} ») ; д=\mathrm{d}=/ \mathrm{d} / ; \mathrm{e}=$ $\mathrm{e}=/{ }^{\mathrm{j}} \mathrm{e} / ; \ddot{\mathrm{e}}=\ddot{\mathrm{e}}=/{ }^{\mathrm{j}} \mathrm{o} /\left(\right.$ siempre acentuado) $;$ ж $=\check{\mathrm{z}}=/ \mathrm{z}_{\mathrm{o}} / ; \mathrm{s}=\mathrm{z}=/ \mathrm{z} / ;$ и $=\mathrm{i}=/ \mathrm{i} / ;$ й $=\mathrm{j}=/ \mathrm{j} / ; \kappa=\mathrm{k}=$ $/ \mathrm{k} / ;$ л $=\mathrm{l}=/ \mathrm{l} / ; \mathrm{M}=\mathrm{m}=/ \mathrm{m} / ; \mathrm{H}=\mathrm{n}=/ \mathrm{n} / ; \mathrm{o}=\mathrm{o}=/ \mathrm{o} /(/ \mathrm{\partial} /$ en posición átona $) ; \Pi=\mathrm{p}=/ \mathrm{p} / ; \mathrm{p}=\mathrm{r}=$ $/ \mathrm{r} / ; \mathrm{c}=\mathrm{s}=/ \mathrm{s} / ; \mathrm{t}=\mathrm{t}=/ \mathrm{t} / ; \mathrm{y}=\mathrm{u}=/ \mathrm{u} / ; \mathrm{\phi}=\mathrm{f}=/ \mathrm{f} / ; \mathrm{x}=\mathrm{ch}=/ \mathrm{x} / ; \mathrm{u}=\mathrm{c}=/ \mathrm{ts} / ; \mathrm{u}=\check{\mathrm{c}}=/ \mathrm{t}_{6} / ; \amalg=\check{\mathrm{s}}=$ $/ \mathrm{s} / ;$ щ $=\check{\mathrm{s} \check{c}}=/ 6: / ; \mathrm{b}="=/-/ ; \mathbf{b}=\mathrm{y}=/ \mathrm{i} / ; \mathbf{b}=$ ' (o bien tilde sobre la consonante precedente $)=$ $/ \mathrm{j} / ; \ni=\dot{\mathrm{e}}=/ \varepsilon / ; ю \mathrm{ju}=/{ }^{\mathrm{j}} \mathrm{u} / ;$ я $=\mathrm{ja}=/{ }^{\mathrm{j}} \mathrm{a} /$.

2. Ucraniano: vale lo dicho para el ruso, con la salvedad de que $\mathrm{r}=\mathrm{h}=/ \mathrm{h} / ; \mathrm{r}=\mathrm{g}=/ \mathrm{g} / \mathrm{e}=\mathrm{e}=$ $/ \varepsilon / ; \epsilon=\mathrm{je}=/ \mathrm{je} / ; \mathrm{i}=\mathrm{i}=/ \mathrm{i} / ;$ и $=\mathrm{y}=/ \mathrm{I} / ; \mathrm{i}=\ddot{\mathrm{i}}=/ \mathrm{ji} / ;$ al signo $\mathrm{ъ}$ del cirílico ruso lo sustituye ', en ucraniano, que transliteramos como "; $\mathbf{b}=$ ' (o bien tilde sobre la consonante precedente) $=/ \mathrm{j} /$.

3. Bielorruso: vale lo dicho para el ruso, así como lo relativo a las grafías $\mathrm{r}, \mathrm{r}$, i, ъ у ь en ucraniano; además, $\breve{y}=/ w /=\breve{u}$, y, en lugar de la letra щ rusa, el bielorruso emplea шч = ̌̌š $=/ 6: /$. 
consultadas, solo Witold Klinger, ya en el siglo XX, profundizó en la cuestión (Klinger 1947, 1949 y 1960). Nosotros, dentro de un proyecto más amplio de estudio comparativo entre rusalki, sirenas y ninfas, nos ocuparemos aquí de una de las afinidades más notorias entre las rusalki y las ninfas de la mitología clásica: la que se refiere a su hábitat. Pero, antes de continuar, debemos advertir ya que la comparación entre las mitologías clásica y eslava se basa en testimonios de índole muy diferente y procedentes de contextos culturales bastante distintos, como veremos a continuación.

\subsection{Observaciones sobre las fuentes empleadas}

En el caso de lo que llamamos "mitología clásica", existe un consenso tácito en que su estudio se basa en alusiones más o menos detalladas por parte de autores literarios que escribieron en griego o latín en un período que abarca desde el siglo VIII a. C. hasta el V d. C., o bien en representaciones a cargo de artistas plásticos que trabajaron, en ese mismo marco temporal, en Grecia y sus colonias o en el Imperio Romano. Para el estudio de la mitología eslava, nos basamos en textos de tradición oral, anotados por folkloristas y etnógrafos de boca de personas que no son autores de literatura escrita; más raramente podemos contar con imágenes procedentes de las artes decorativas practicadas en medios rurales o, más en general, por personas ajenas a la tradición artística académica. Tales testimonios comenzaron a ser recopilados y publicados a partir del siglo XVIII (muy escasos, aunque también muy dignos de atención, son los testimonios anteriores).

En el caso de las rusalki, la mayoría de los testimonios disponibles (dejando aparte los que son descripciones, perífrasis o exposiciones elaboradas por los estudiosos) pertenecen a un género literario de tradición oral que, entre los eslavos orientales, se denomina con las palabras «быличка» (bylička) у «бывальщина» (byvál’ščina). En el estado actual de nuestros conocimientos, dichos términos carecen de equivalente exacto en español; pero, dado que ambos contienen la raíz del verbo «быть» (byt'), es decir, "ser, existir", podríamos traducirlos aproximadamente como "cosillas que fueron", o bien "sucedidos"3. Pero hay que especificar algo más: las bylički (plural de bylička) son relatos sobre encuentros con lo que en ruso se denomina «нечистая сила» (nеčístaja sila, literalmente "fuerza impura”), esto es, con personajes como las rusalki o los espíritus del bosque, del agua, etc., y lo más importante es que el protagonista de los encuentros narrados en

3 Agradecemos a Jesús Antonio Cid, de la Universidad Complutense de Madrid (correo electrónico del 9 de enero de 2013) la sugerencia de traducir por "sucedidos". 
dichos relatos es el mismo narrador, o bien un conocido o familiar del narrador. En ese sentido, se trata de supuestos testimonios oculares. El hecho es que, según la folklorista I. V. Karnaúchova, sus informantes insistían en que tales relatos no eran cuentos, sino "verdad verdadera" (Карнаухова 1928: 91, y Molina Moreno 2012: 18; sobre la bylička como género, vid., por ejemplo, Зиновьев 1974 у 1987, у Левкиевская 2008).

Por supuesto, los autores de literatura escrita (Puškin, Gógol', Lérmontov, Ševčenko, Lesja Ukraïnka, etc.) y los artistas plásticos con formación académica (Konstantín Makóvskij, Iván Nikoláevič Kramskój, Konstantín Vasíl'ev, Iván Jákovlevič Bilibin, Víktor Korol’kov, Sergéj Petróvič Panasenko, etc.) también dieron y siguen dando cabida en sus obras a las rusalki y a otros personajes de la mitología eslava. Por su parte, Píndaro, Eurípides, Mirón, Praxíteles, Horacio u Ovidio, por ejemplo, habían hecho lo propio en su época con los mitos que nosotros llamamos "clásicos"; pero, en este último caso, nos faltan casi por completo los apuntes de etnógrafos y folkloristas que recogieran la tradición oral de los antiguos griegos y romanos con la exigencia de fidelidad de los investigadores modernos: solo hallamos algo remotamente comparable en las obras de Pausanias o de algunos historiadores. Sin embargo, tanto los antiguos escritores en griego y latín, como los informantes entrevistados por los modernos estudiosos del folklore eslavo, eran, cada uno a su manera, portadores de sus respectivas tradiciones míticas. Unos y otros (insistimos: cada uno a su manera) elegían determinados motivos, personajes o rasgos de esos personajes, los modificaban, los desarrollaban, los adaptaban a su gusto y al de la época en la que vivían.

\subsection{Planteamiento del problema y descripción del método empleado}

En las páginas que siguen, contando con las puntualizaciones del subapartado anterior, intentaremos responder a la cuestión que da título a este trabajo: ¿son las rusalki las ninfas eslavas de las aguas? Obsérvese que hemos dicho "son" (en vez de "eran"), puesto que vamos a estudiar, de acuerdo con la intención de esta revista, un fenómeno de la tradición oral de los siglos XX y XXI. El método que emplearemos para dar respuesta a esa cuestión consistirá en presentar, traducidos al español por el autor de este artículo, los siguientes testimonios:

a. El del primer autor que identificó a las rusalki con las ninfas, y

b. Textos de la tradición oral, anotados durante los siglos XX y XXI en distintas regiones de Bielorrusia, Ucrania y Rusia (de oeste a este y de sur a norte), en las que, según los investigadores, se atestiguan creencias sobre el hábitat de las rusalki. Dentro de cada región, el orden de la exposición 
obedecerá a las fechas en las que los testimonios fueron anotados y/o publicados (desde comienzos del siglo XX hasta 2012).

A través de los textos mencionados, veremos que la asociación de las rusalki con el agua, compartida con las ninfas de la Antigüedad clásica, se mantiene viva en la imaginación de los actuales portadores de la tradición oral, en gran parte del territorio eslavo oriental; pero también podremos comprobar que las rusalki no son exclusivamente ninfas de las aguas.

\section{LOS PRIMEROS TESTIMONIOS DE LA PALABRA RUSALKA}

Aunque esta publicación se refiere a los siglos XX y XXI, debemos tomar, como punto de partida, algunos de los textos más antiguos en los que aparece la palabra rusalka como denominación de un personaje mitológico, pues en ellos, además, se compara a las rusalki con las ninfas. El primer texto que permite saber algo sobre las rusalki es la traducción rusa abreviada, publicada en 1722, de la obra del historiador croata Mavro Orbini Origen de los eslavos y progreso de su imperio, que apareció originalmente en italiano en 1601. Mavro Orbini, al hablar de la religión eslava pagana, tradujo lo que había dicho al respecto el historiador bizantino Procopio, en el siglo VI: que los eslavos rendían culto a las ninfas, a lo que el traductor ruso añadió la glosa: "esto es, a las rusalki" (Orbini 1601: 18 de la ed. de 16o6; cf. Мауроурбин 1722: 14)4 A Mavro Orbini remitió, por cierto, el historiador ruso del siglo XVIII V. N. Tatíščev, cuando trató del paganismo eslavo y volvió a decir que las rusalki eslavas eran como las ninfas de la Antigüedad clásica (Татищев 1768: 17 = libro I, parte I, capítulo IX).

Pero la primera descripción que conocemos de las rusalki se halla en la primera monografía rusa sobre la mitología eslava, obra de M. I. Popov, que fuera publicada en San Petersburgo en 1768, con el título Descripción de la antigua mitología eslava pagana. Dice Popov:

Rusalki. Son las ninfas eslavas. Las consideraban diosas de las aguas y de los bosques; tal vez había más de un linaje de ellas, como entre los griegos. Los eslavos las reverenciaban y les hacían ofrendas. Entre el pueblo sencillo, todavía hoy circula la fábula de que se las ve a veces a la orilla de los lagos y ríos, lavándose y peinando sus verdes cabellos, y a otras, columpiándose en

\footnotetext{
4 Mavro Orbini se basó en Procopio de Cesarea, Sobre las guerras, 7, 14, 24. En el s. XII, el sabio cronista checo Cosmas de Praga mencionó también el culto que los eslavos rendían a las oréades, dríades y hamadríades, es decir, a las ninfas de las montañas y de los árboles (vid. Chronica Bohemorum, I, 4, en Meyer 1931: 18, y Bretholz-Weinberger 1923: 10).
} 
los árboles. Como se ve, todavía dura el contagio de antiguas supersticiones (Попов 1768: 32)5.

También Popov, como vemos, identificó a las rusalki con las ninfas, según habían hecho antes que él Tatíščev y el traductor de Mavro Orbini. Popov no se proponía un estudio exhaustivo de las afinidades y diferencias entre esos personajes; su identificación entre rusalki y ninfas tiene un carácter ilustrativo, de ejemplo. Pero lo que dice Popov sobre las rusalki hace pensar que la identificación no está del todo infundada: al menos, el hábitat natural de estos personajes femeninos coincide con el de muchas clases de ninfas ${ }^{6}$.

Entre otros autores que también señalaron la afinidad entre las rusalki y las ninfas, Snegirëv, en su obra de 1839, dijo algo de gran interés: las rusalki habitan en los ríos; pero, desde el día de la Trinidad hasta el de San Pedro, deambulan por la tierra, se aposentan en los árboles (sobre todo en los robles) y se balancean en sus ramas (Снегирёв 1839: 7). He ahí, dentro de las fuentes manejadas, la primera referencia a la alternancia en el hábitat de las rusalki (cf. después Афанасьев 1865-9: tomo 3, 144; Зеленин 1916: 166-76 de la ed. de 1995; Виноградова 2009б: 497; Molina Moreno 2012: 35-45). Esa variación del hábitat constituye una importante diferencia con respecto a las

5 Las traducciones al español son nuestras; a la vista de las fuentes consultadas, es la primera vez que se traducen al español los textos que presentamos.

${ }^{6}$ Las ninfas habitaban en los bosques, fuentes, ríos y prados, según podemos ver en los siguientes testimonios: Homero, Ilíada, 20, 8-9; ibid., 24, 614-6; Odisea, 6, 105-6 у 123-4; Himno homérico a Afrodita, 97-9; Sófocles, Filoctetes, 1454; Apolonio de Rodas, 3, 881-3; ibid., 1219-20; Calímaco, Himno a Deméter, 36-8; Dionisio de Halicarnaso, Antigüedades romanas, 1, 38, 1; Varrón, Menippeae, fr. 130, citado por Nonio Marcelo, De compendiosa doctrina, 4, p. 250 M. (= p. 377 Lindsay); Gratio, Cynegetica, 16-8; Virgilio, Bucólicas, 2, 45-8; ibid., 10, 9-10; Ovidio, Metamorfosis, 1, 639-44; ibid., 4, 296-304; 6, 451-3; 9, 649-65; 13, 602-3; 14, 320-45 у 785-9; Fastos, 2, 585-616; T. Calpurnio Sículo, 2, 14; ibid., 4, 132-6; Séneca, Fedra, 777-84; Silio Itálico, 4, 289; Estacio, Silvas, 1, 5, 6; ibid., 2, 6, 90-102; Apolonio, Léxico homérico, p. 116 Bekker; Clemente de Alejandría, Protréptico, 4, 58, 2; Plutarco, Sobre la decadencia de los oráculos, 415 F 1-5; Elio Herodiano, De prosodia catholica, vol. 3, 1, p. 361 Lentz; Frínico, Preparación sofística, p. 27 De Borries; Himno órfico núm. 51, 1-10; Porfirio, La gruta de las ninfas, 8; ibid., 10 y 12; Quinto de Esmirna, Posthomerica, 2, 585-92; Servio, Comentario a la Eneida, 1, 500; id., Comentario a las Bucólicas, 10, 9 y 62; Himerio, Or., 16, líneas 15-9 Colonna; ibid., 38, líneas 80-2 Colonna; Nonno de Panópolis, Dionisíacas, 2, 54-9; ibid., 11, 322-3; 14, 145-6; 22, 390-7; 23, 272-9; 24, 24-30; 32, 285-92; 40, 545-52; 42, 108-9; 44, 137-46; Coluto, Rapto de Helena, 1-6 y 363-4; Esteban de Bizancio, Ethnica, p. 472, líneas 20-1 Meineke; Hesiquio, v, 16; Focio, Léxico, v, p. 285, líneas 9-10, y p. 298, líneas 7-8 Porson; Suda, v, 14 y 305; Miguel Pselo, Opuscula logica, physica, allegorica, alia, 45; Eustacio, Comentario a la Ilíada, vol. 2, p. 235, líneas 7-11; vol. 4, p. 152, líneas 2-3, y p. 962, líneas 10-12 Van der Valk; id., Comentario a la Odisea, vol. 1, p. 255, líneas 9-10; ibid., p. 385, líneas 14-6; ibid., vol. 2, p. 26, líneas 44-6; ibid., pp. 41-2; ibid., p. 80, líneas 15-17 Stallbaum; Etymologicum Magnum, p. 604 Kallierges; Anthologia Graeca, 9, 328; ibid., 9, 663; 9, 668; 9, 814; escolio a la Ilíada, 6, 21-2; ibid., 20, 8; escolio a la Odisea, 10, 350, e ibid., 13, 104. 
ninfas de la mitología clásica. Pues bien: dicha diferencia sigue atestiguándose en nuestros días, como vamos a ver a continuación.

\section{EL HÁBITAT DE LAS RUSALKI EN EL FOLKLORE ESLAVO}

\section{ORIENTAL DE LOS SIGLOS XX Y XXI}

\subsection{En el Poles'e}

Comenzaremos por una vasta comarca llamada Poles'e, que abarca parte del sudeste de Polonia, sur de Bielorrusia y Rusia, y norte de Ucrania (figs. 1-4)7.

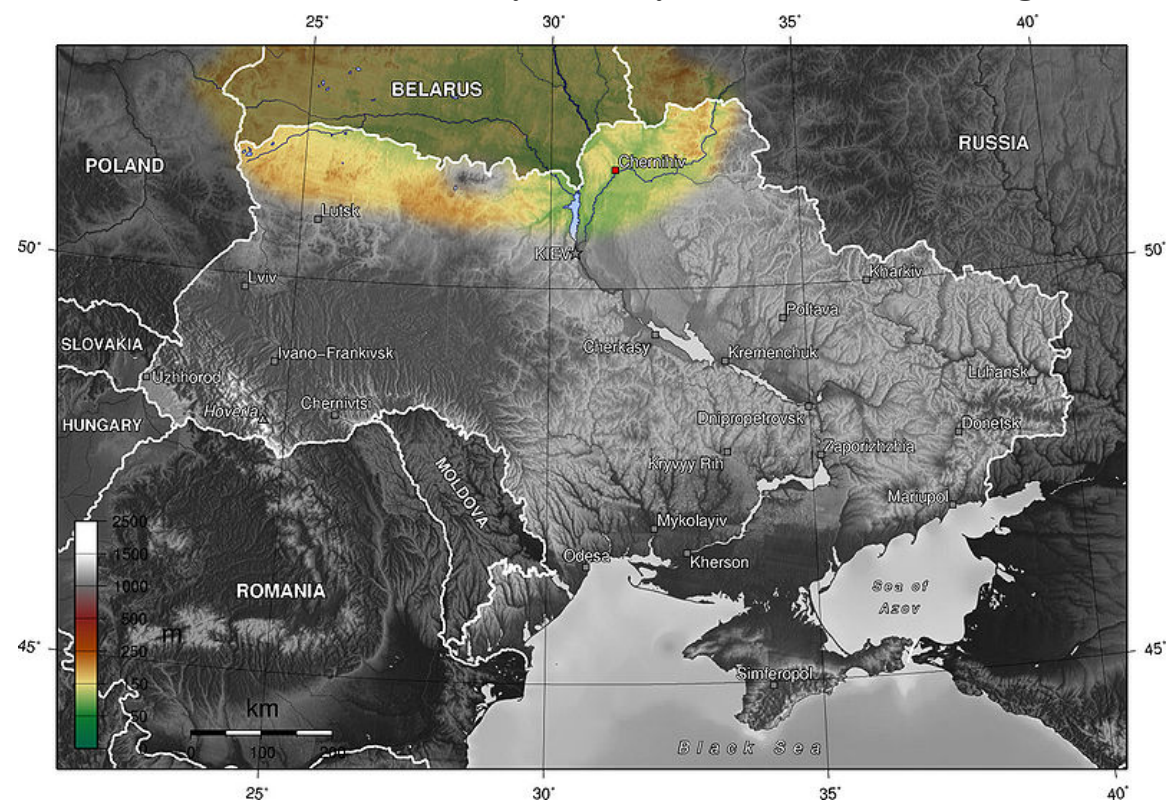

Fig. 1. Mapa del Poles'e ${ }^{8}$.

7 La delimitación más precisa de qué regiones de esos países se incluyen en el Poles'e es objeto de discusión (vid. Molina Moreno: 2012: 3, n. 11). Nosotros, en este trabajo, nos ceñiremos a las regiones exploradas por Nikita Il'ič Tolstój y sus colaboradores (vid. Виноградова 2000: 394-8); por lo que se refiere a los materiales sobre las rusalki, estos proceden de las regiones de Brest y Hómel', en Bielorrusia; de Volýn', Rivne, Žytómyr, Kýïv y Černíhiv (más conocidas entre nosotros por sus nombres rusos, Kíev y Černígov), en Ucrania, y Brjansk y Kaluga, en Rusia. En nuestra figura 1, el Poles'e se destaca en color amarillo y ocre sobre las fronteras de Polonia, Ucrania, Bielorrusia y Rusia; en la figura 2, pueden verse las regiones de Ucrania que pertenecen al Poles'e. En las figuras 3 y 4 se señalan, respectivamente, las regiones de Bielorrusia y Rusia exploradas por el grupo de Nikita Il’ič Tolstój. En la figura 4, constan, además, otras regiones de Rusia mencionadas en este trabajo.

${ }^{8}$ Mapa tomado de http://be.wikipedia.org/wiki/Выява:Ukraine_Polissya_depression_en.jpg, consultado el 14 de diciembre de 2011. 


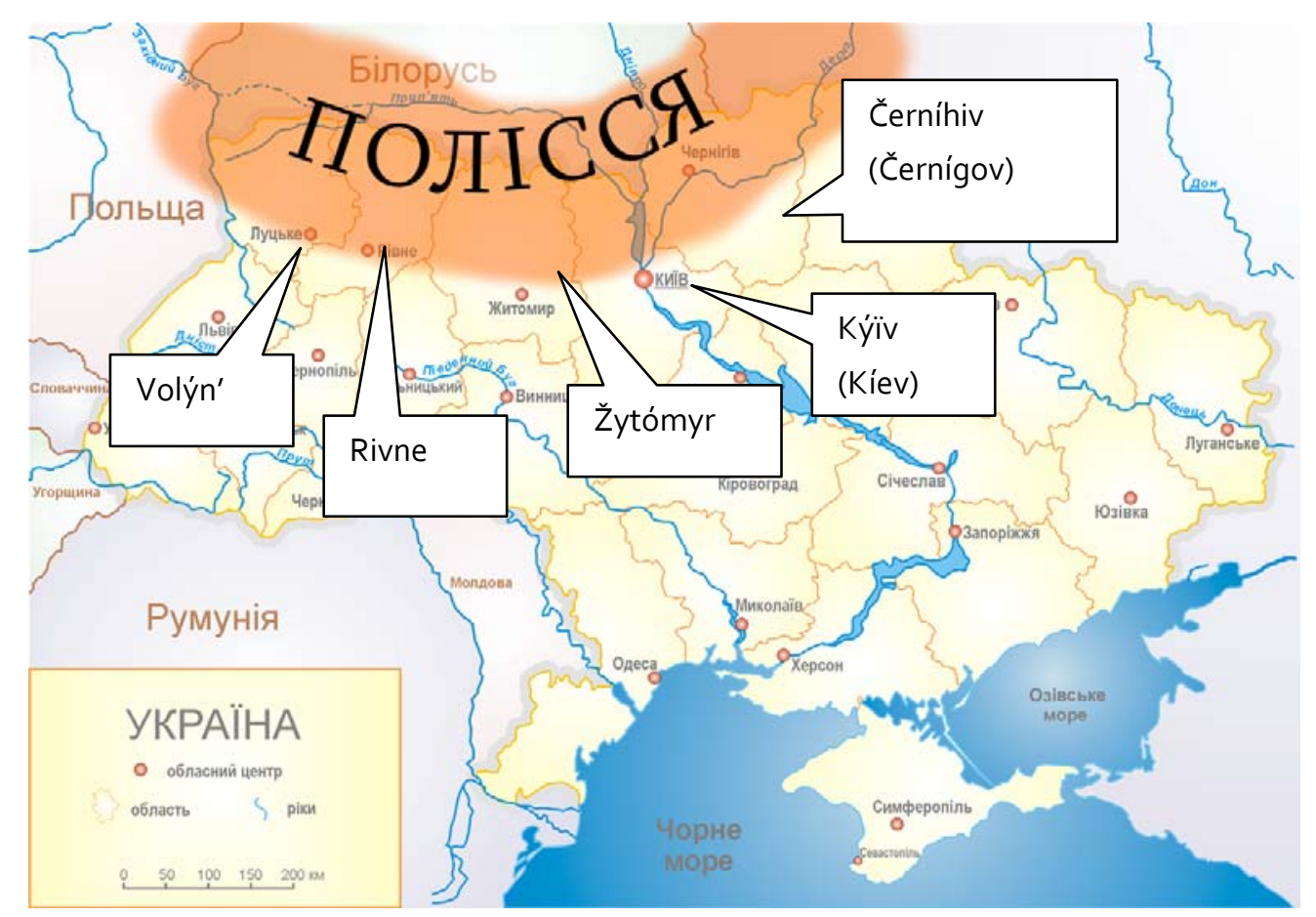

Fig. 2. El Poles'e (zona naranja) sobre un mapa de Ucrania9.

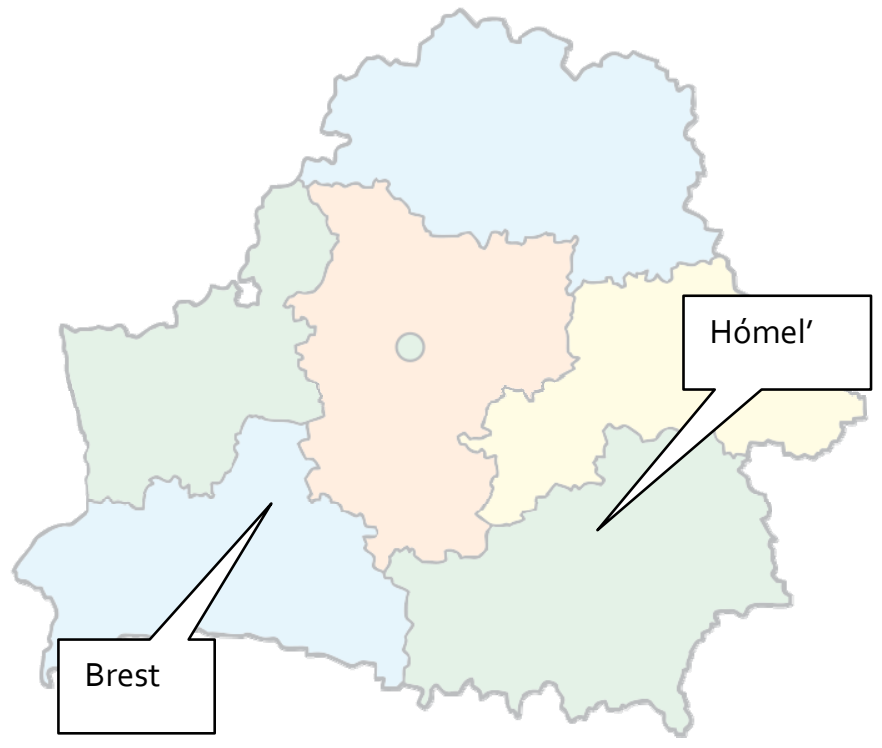

Fig. 3. Mapa de Bielorrusia, donde se señalan las regiones que pertenecen al Poles'e ${ }^{10}$.

9 Mapa tomado de http://id.wikipedia.org/wiki/Polesia (7 de marzo de 2012), completado y rotulado por el autor de este artículo.

10 Mapa tomado de http://uk.wikipedia.org/wiki/Файл:Belarus_provinces_blank.svg (7 de marzo de 2012), completado y rotulado por el autor de este artículo. 


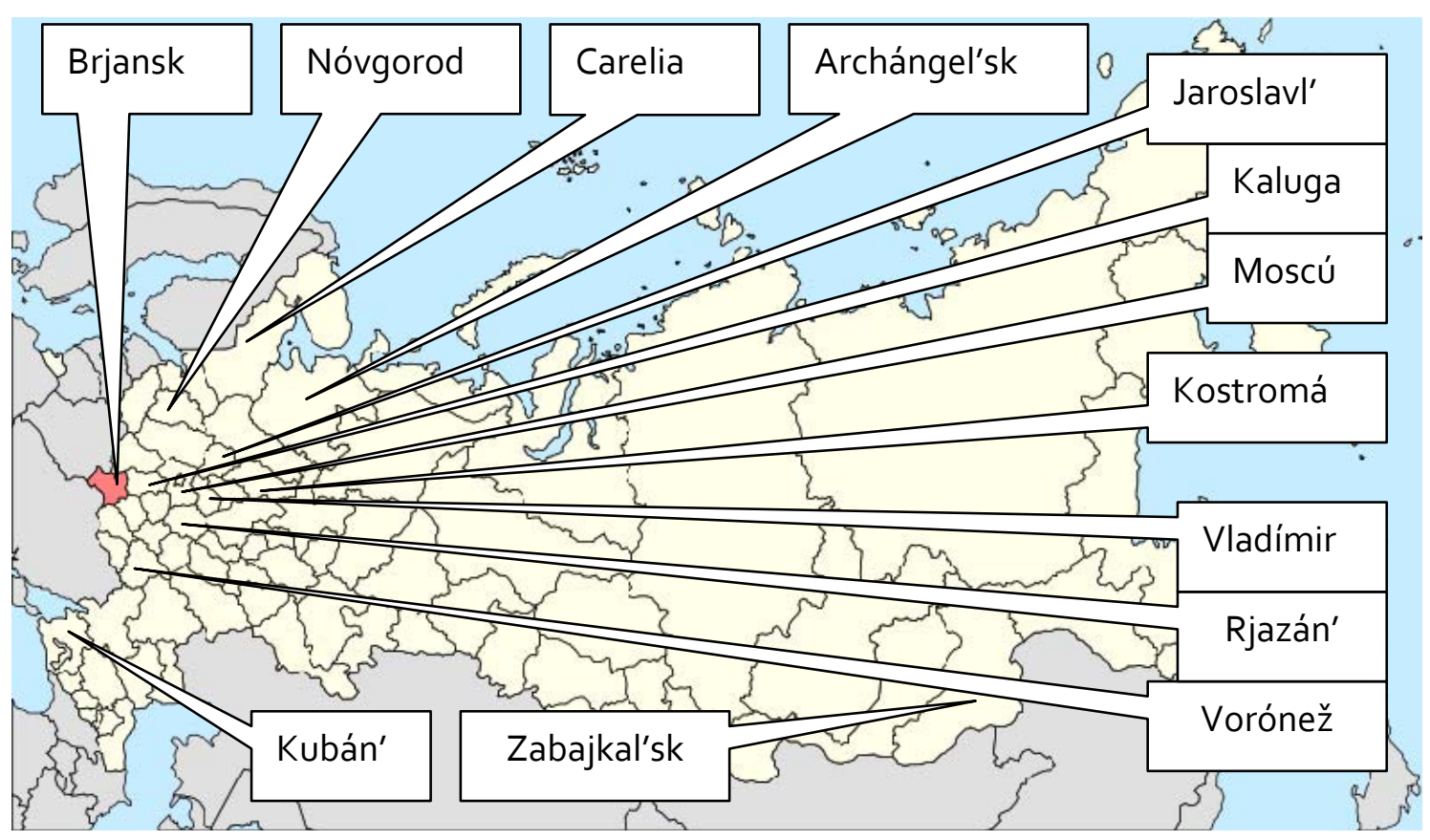

Fig. 4. Mapa de Rusia, donde se señalan las regiones mencionadas en este trabajo ${ }^{11}$.

Por esa comarca del Poles'e, en 1974, el académico Nikita Il’ič Tolstój (sobrino nieto del autor de Guerra y paz) emprendió, junto con sus colaboradores del Instituto de Eslavística y Balcanística de la Academia de Ciencias de la U.R.S.S., una serie de expediciones folklorísticas y dialectológicas que se prolongaron hasta 1989. Según las notas sobre las rusalki, tomadas en dichas expediciones, las rusalki aparecen, ante todo, en los campos de cereal y, en segundo lugar, en el agua; además, es muy interesante el hecho de que esa variabilidad de hábitats dependa, según muchos testimonios, de la época del año (Виноградова-Левкиевская 2012: 538; testimonios anteriores a las expediciones de N. I. Tolstój, en Molina Moreno 2012: 35-45). Ya en el primer párrafo de la introducción a este trabajo se ha señalado que las rusalki aparecen en la semana anterior o siguiente a la Trinidad (siete semanas después de Pascua). Esa semana se llama, según las zonas, "semana de las rusalii", "semana de la Trinidad", "semana de los juegos" o "semana verde" (testimonios de esas denominaciones, en relación con el hábitat y la época de aparición de las rusalki, en Зеленин 1916: 152, 162, 204, 243 у 252 [ed. de 1995]; en general, vid. Виноградова 2009а; Виноградова 2009б: 497; Агапкина 2009; Агапкина 2012). Por ejemplo, una mujer de Rémčicy (distrito Sárnens'kyj, región de Rivne, Ucrania) contó,

${ }^{11}$ Mapa tomado de http://ru.wikipedia.org/wiki/Файл:Map_of_Russia_-_Bryansk_Oblast_ (2008-03).svg (7 de marzo de 2012), completado y rotulado por el autor de este artículo. 
en 1983, a N. K. Gavriljuk, del grupo de N. I. Tolstój: "Cuando una persona se ahoga en la semana de las rusalii se convierte en rusalka. Una rusalka tiene una mitad de persona y otra mitad de pez. Sale del agua, va al centeno. En el día de las rusalii, hacen cosquillas en el agua” (Виноградова-Левкиевская 2012: 515, núm. 190). También en Ucrania, al este de Rivne, está la región de Žytómyr, de la que procede esta bylička:

Las rusalki el día de la Trinidad salen del agua y, quién te dice, viven en los bosques. Son los juegos, de lunes a lunes, la semana de la Trinidad. Nuestras chicas fueron el día de la Trinidad a recoger bayas. Qué sorpresa: en un abedul se columpian y se ríen dos rusalki. Llevan el pelo suelto y cintas a la manera de Ucrania, a nuestro estilo. Las chicas salieron corriendo, en cuanto vieron a las rusalki (Виноградова-Левкиевская 2012: 602, núm. 521).

Y, al este de la región de Žytómyr, en la de Černíhiv, en 1980, A. B. Ključévskij anotó: "Las rusalki viven en el centeno o en el agua. En invierno, en el agua; en la semana de las rusalii, salen a los campos y a los bosques" (Виноградова-Левкиевская 2012: 524, núm. 232). También en Černíhiv y en 1980, fueron anotadas estas palabras: "Veían a las rusalki. Salen del río unas chicas bonitas, los cabellos largos, las cejas negras, una mitad es una cola de pez. Se sientan desnudas en la arenita y cantan. Entre tres cantan a una sola voz. Los chicos iban, las veían” (Виноградова-Левкиевская 2012: 515, núm. 194). Y, en esa misma región de Černíhiv, en 1985, se contaba lo siguiente: "Las rusalki viven en el agua. Cuando muere un niño en la semana verde, se convierte en rusalka. Se aparece vestida de blanco. El día de San Elías no puede uno bañarse, porque las rusalki hacen cosquillas en el agua" (Виноградова-Левкиевская 2012: 542, núm. 306).

Podría parecer esperable que estas criaturas, relacionadas, al menos en parte, con el agua, tengan cola de pez, como hemos visto en el párrafo anterior (cf. testimonios más antiguos en Афанасьев 1865-9: том 2, 246-7; Зеленин 1916: 152, 182 y 217 de la ed. de 1995, y en Molina Moreno 2012: 11-13 y 35). Volveremos a encontrar esa creencia en otras partes del territorio eslavo oriental, que examinaremos más adelante; pero, en el Poles'e, predominan, frente a los testimonios mencionados, los que atribuyen a las rusalki una fisonomía enteramente antropomórfica. En cualquier caso, a nuestras protagonistas, independientemente de su aspecto, se las imagina como seres anfibios, como vemos en estas palabras anotadas en la región bielorrusa de Brest, en 1984: "La rusalka... Ya vive en el agua. Decían que sale del mar, nadando. Y vuelven al mar, cuando pasa su estación” (ВиноградоваЛевкиевская 2012: 542, núm. 303). 
Los textos que hemos presentado hasta ahora ya nos han enseñado que esa "estación" de las rusalki tiene lugar en torno a la Trinidad; pero, además, el hábitat de las rusalki también puede variar en función de las horas del día, según estas palabras anotadas en Hómel' (Bielorrusia, al este de Brest), en 1983: "Las rusalki están en el agua de día; de noche, en el centeno. Dicen: antes de la Trinidad no vayáis al agua, que, si no, las rusalki os pillarán” (Виноградова-Левкиевская 2012: 532, núm. 271). También en 1983, y en esa misma región de Hómel', fueron anotadas dos breves, pero muy interesantes, noticias según las cuales el canto de las rusalki del agua sirve de modelo al canto y a la poesía de los humanos. Una dice así: "Cantaban las rusalki por la tarde, especialmente en primavera. Canta y llora. Salen del agua. Componían las canciones que nosotros cantamos". Y la otra: "Las doncellas del agua salen a la orilla, cantan canciones, y luego los poetas se las apropian” (Виноградова-Левкиевская 2012: 606, núms. 540-541; cf. Molina Moreno, 2013).

Debemos continuar explorando la región de Hómel', más concretamente su distrito Vétkaŭski, de donde proceden algunos testimonios anotados en época bastante reciente. Uno de ellos atestigua, en forma muy peculiar, la pervivencia de la creencia en las rusalki y en su hábitat acuático:

A propósito de las rusalki, mamá siempre nos metía miedo: “iEn el centeno hay rusalki! iNo vayas al campo, que hay rusalki en el centeno!”. Ahora no hay; pero mamá nos metía miedo: “iNo vayas al campo, que allí hay rusalki!”. Y era la costumbre. Yo era pequeña, todavía no iba al colegio. Y eso se lo han inventado ya ahora, lo de que la octava semana, las rusalki corretean, no se puede uno bañar, porque la rusalka te arrastrará al agua. Eso se lo han inventado ahora, en los años noventa (Лопатин 2007: 285, núm. 46).

Es sorprendente que la informante considere un invento de los años noventa la creencia de que las rusalki aparecen en la octava semana (hay que sobreentender "a partir de Pascua") y que entonces no puede uno ir a bañarse en ríos o lagos, porque las rusalki arrastran a la gente al fondo. Al parecer, la informante ignora la existencia de testimonios más antiguos de esa creencia (cf., por ejemplo, los recogidos en la misma región de Hómel' en la década de 1980, en Виноградова-Левкиевская 2012: 661-2; en otras regiones del Poles'e, ibid., 666-9; otros más antiguos pueden hallarse en Зеленин 1916: 163, 166, 196, 198, 242-3 de la ed. de 1995); pero sus palabras son indicio de que las tradiciones relativas a las rusalki están vivas. También hay que observar, por otra parte, que el texto atestigua que las rusalki no son exclusivamente criaturas acuáticas; más aún, la informante las considera ante 
todo como seres del campo. Sin embargo, en la imaginación de otros informantes predomina la vinculación de las rusalki con el agua, e incluso no admiten que nuestras protagonistas puedan encontrarse en otros medios:

Cuando yo corría al centeno, mi abuela decía: "Va a haber una rusalka". ¿Qué es eso de una rusalka? Yo me la imaginaba como algo del río. No podía entender cómo iba a correr detrás de mí por el centeno (Лопатин 2007: 288, núm. 71).

Incluso la ausencia de masas de agua en una determinada región basta para que una informante justifique que en dicha región no se hablara de las rusalki:

En nuestra tierra no había masas de agua como esas, de las rusalki no se hablaba. Las rusalki... Es una chica bonita. No tiene piernas, sino una cola de pez. Yo veo todas las noticias, en cuanto sacan algo en el televisor. En nuestra tierra de eso no hay. Había cuentos, nuestras madres nos los contaban, que había rusalki, muy hermosas, que salían del mar nadando; pero en nuestra tierra es que no había mares (Лопатин 2007: 289, núm. 74).

Es evidente que la informante imaginaba a las rusalki conforme al modelo constituido por las sirenas de Copenhague o de Varsovia, es decir, como muchachas con cola de pez. Por ello, a su vez, las imaginaba como personajes exclusivamente acuáticos; en consecuencia, dado que en su región no hay mar, afirmaba que tampoco hay rusalki. Puede resultar un rasgo de ingenuidad casi conmovedora que la informante aludiera a las noticias que veía por la televisión, para apoyar su afirmación de que, en su zona, no hay rusalki: ello sugiere que, de una manera quizá inconsciente, creía que tales personajes pueden existir en la realidad. Y, por último, también es muy significativo que la informante conociese a las rusalki como personajes de cuento, en clara oposición a la creencia en su realidad. Debemos recordar, en estos momentos, lo que ya dijimos en nuestra introducción: la mayoría de los testimonios sobre las rusalki pertenecen a un género que, desde el punto de vista de los portadores de la tradición oral eslava oriental, se distingue claramente del cuento: las bylički son "cosillas que pasaron", y quienes las cuentan las consideran "verdad verdadera". Como en el entorno del que procede la noticia no se daban las condiciones para poder considerar "verdad verdadera" un relato sobre las rusalki, la informante afirma que nuestras protagonistas eran personajes de cuento.

Para terminar nuestra búsqueda de rusalki en el Poles'e, debemos señalar que, en la región de Brjansk (Rusia), en 1982, fue anotado el siguiente texto: 
A las rusalki se las podía ver, corrían entre el centeno, por la noche. En la semana de los juegos es su fiesta, merodean por el centeno. Después se iban a los campos de centeno. Quién sabe dónde se metían. También las había en el río (Виноградова-Левкиевская 2012: 525, núm. 234).

\subsection{Kubán’}

Al este de Ucrania, en el SE de Rusia, se encuentra la región de Kubán', también llamada “territorio de Krasnodar". En la década de 1920, más concretamente el 31 de diciembre de 1923, en el poblado cosaco de Íl'skaja, situado en dicha región, el investigador O. S. Bežkóvič anotó:

El mismo abuelo Černucha me habló de las rusalki. Que en 1885 ó 1886, en su pueblo, el segundo día después de la Santísima Trinidad las rusalki hicieron cosquillas en el agua a una chica de 16 años, de apellido Dobrosél'skaja. La chica se bañaba de día, y dicen los que lo vieron que se puso a reír hasta que se ahogó (Бежкович †2008: 59-60).

En la misma región de Kubán', en la década de 1980, tuvo lugar una expedición folklorístico-etnográfica, dirigida por el profesor N. I. Bóndar', cuyos resultados se publicaron en 1989. Durante dicha expedición, en una stanica (poblado cosaco) llamada Nikoláevskaja, los investigadores se encontraron con personas que creían que las rusalki "se hallan todo el tiempo en el agua. Una vez al año, el jueves antes de la Trinidad, las rusalki salen del agua y se columpian en los árboles. Ese día se vuelven peligrosas. Pueden hacer cosquillas hasta causar la muerte" (Бондарь 1989: 50)12. Podemos observar también aquí la alternancia estacional del hábitat de las rusalki, que las distingue de las ninfas de la mitología clásica. Por último, en la región de Kubán' también se atestiguaba, en la década de 1980, la creencia en una clase muy especial de rusalki, a las que ya hemos aludido: las que tienen torso de mujer y, en lugar de piernas, cola de pez (Бондарь 1989: 50; testimonios de otras épocas y de otras partes del territorio eslavo oriental, en Molina Moreno 2012: 11-2, especialmente la n. 26 en p. 11).

12 Es muy curioso que esas mismas creencias se atestiguaran un siglo antes de la expedición dirigida por el profesor Bóndar'; cf. Арканников 1883: 575. Agradecemos al profesor Bóndar' que nos facilitara el manejo de su publicación, durante nuestra estancia en Krasnodar en el año 2007. 


\subsection{Vorónež}

Si avanzamos hacia el norte, desde Kubán', tras atravesar la región de Rostov, nos hallaremos en el territorio de Vorónež, donde, en los últimos años del siglo XX y en los primeros del XXI, también se atestiguó la creencia de que las rusalki aparecen en ríos y lagos. De los testimonios que conocemos, elegimos uno, anotado en 1996, y otro anotado en 2004. El primero es un relato narrado por Aleksandra Stepánovna, nacida en 1912, y anotado por Ju. A. Bábuškina, E. V. Paškova e I. V. Sonova en un pueblo llamado Stáraja Tojda (distrito Ánninskij, región de Vorónež):

Una vez, en verano, unas mujeres habían ido al río a lavar la ropa. Se quedaron hasta que oscureció. Y, cuando en el cielo apareció la Luna llena, las mujeres vieron cómo por la corriente del río navegaba en una balsa una chica de extraordinaria belleza, porque la balsa no causaba ninguna agitación en el agua. Parecía que la balsa y la chica volaban sobre el agua. Desde entonces todas hablaban de una chica a la que su madre había lanzado una maldición y que se había ahogado y convertido en una rusalka (Пухова 2008: 254, núm. 661).

Y, en 2004, en un pueblo llamado Petróvskoje (distrito Borisoglébskij, región de Vorónež), T. Kudriávceva anotó la siguiente bylička, de boca de N. A. Š́škina, nacida en 1951:

Mi abuela contaba muchas cosas de las rusalki. Y no que allí, en un sitio, algo, sino que esto pasó en Petróvskoje. Allí, más allá de Petróvskoje está la hondonada Čertínskaja. En ella ha quedado muy poca agua. Hay allí unos manantiales, unos manantiales maravillosos. Bueno, pues mi abuela contaba: allí salían rusalki. Cuando el abuelo iba a pescar, llega y dice: "Pues yo hoy he visto otra vez a las chicas". Por alguna razón las llamaba "chicas". Prácticamente no dejaban que se les acercaran, según lo que cuentan. Figúrate que vas normalmente, una mañana de niebla, y de pronto hete aquí ya un canto en voz baja, en voz baja, ya un susurro fuerte. $O$ un canto en voz baja, o un susurro fuerte. Y vuelves sin querer, dice, la cabeza, y allí, bueno, qué hermosura. Son de una blancura mate, tienen el cuerpo mate. Todas iban prácticamente sin ropa. Él no vio si tienen cola o no tienen cola, eso no lo vio; pero una belleza extraordinaria. $\mathrm{Y}$ en la orilla se peinaban sus cabellos. Figúrate que vas por la mañana y las ves de lejos: están peinando sus cabellos.

¿Qué era aquello? Yo ahora, por ejemplo, pienso que era un espejismo. Puede que él quisiera ver algo. Pero puede que hubiera algo de verdad (Пухова 2008: 251-2, núm. 651). 
En la región de Vorónež, se cuenta también que las rusalki aparecen en el bosque y en el campo, además de en el agua, y que se las ve en todos esos entornos en la semana siguiente a la Trinidad (Пухова 2008: 249, 252-6, 258); pero no hemos hallado testimonios de una alternancia estacional del hábitat de nuestras protagonistas, a diferencia de lo que ocurre en el Poles'e y en Kubán'.

\subsection{Rjazán'}

Continuemos ahora nuestro viaje imaginario hacia el norte de Rusia. Desde Vorónež, tras atravesar las regiones de Lípeck o de Tambov, llegamos a la de Rjazán'. En ella, en la década de 2000, seguía manifestándose la creencia de que las rusalki aparecen en el agua. Por ejemplo, el 10 de septiembre de ese año, la investigadora E. A. Samodelova (Academia de Ciencias de Rusia, Instituto de Literatura Universal, sección de folklore) entrevistó a K. A. Polikúšina, pensionista, oriunda del distrito Š́lovskij, pero que, en el momento de la entrevista, vivía en Konstantínovo, distrito Rýbnovskij, región de Rjazán' (Rusia central). Las palabras de la señora Polikúšina reflejan creencias que ya conocemos por otros testimonios: en particular, por lo que aquí nos concierne, la variabilidad del hábitat de las rusalki. Además, en la entrevista se muestra también la influencia, en la tradición oral, de manifestaciones artísticas como una ópera (que puede ser la Rusalka de Dargomýžskij o la de Dvořák). Y, por último, también puede observarse el variable grado de escepticismo hacia nuestras protagonistas:

Las rusalki son personas que se ahogaron. Incluso, quizá, conoce usted la ópera, a ver, espere: él la engañó, la abandonó, se fue sin dejar rastro. Ella quedó embarazada y se ahogó: he ahí a una rusalka de esas. Tuvo una niña, una rusalka chiquitina, y al príncipe aquel lo arrastró consigo (la segunda), y él se ahogó (él iba de un lado para otro, la echaba mucho de menos).

Así que personas que se ahogaron. Mujeres solo; pero no hombres. Bueno, como de costumbre. Estaban así, cubiertas con un pañuelo, y tenían trenzas así, bueno, como las personas. Bueno, personas: una persona es una persona, solo que se suicidó. Se llama rusalka. Bueno, había una creencia, puede que no sea verdad; en resumen, que salían del agua. Es un cuento, claro. Salían del agua, solían salir por la noche. Una noche de luna, estaban sentadas en las rocas; donde hay un río o un laguito, allí estaban. Estaban sentadas, cantaban canciones. Pues eso ya no lo sé. No, nosotros no las oímos. Es como un cuento. ¿Acaso puede un ahogado salir del agua? Lo sacaron, lo enterraron, ya no está en el agua, está enterrado, bajo tierra, ahí está. Contaban que unos que se suicidaron, en nuestro pueblo hay unos cementerios de Lázaro, bueno, un agujero, bueno, como una zanja así, 
excavada, de unos dos metros de ancho y, en resumen, una fosa alrededor. Bueno, pues a todos esos, que se suicidaban, no los enterraban en el cementerio, sino allí, allí, al otro lado de la fosa. Se les conmemora cuando florece el centeno, por lo que también van a donde hay centeno. Florece el centeno, y todos se van al centeno. Incluso hay cuentos de esos y todo: están en un mismo sitio, solo que salen por la noche del agua, así, como en los cuentos. Solo que todo eso es tontería. Como en los cuentos, así es aquí también. Solo que en qué fecha, no recuerdo, cuándo las acompañan. Bueno, cuando florece el centeno. Maša ${ }^{13}$, ¿cuándo acompañan a las rusalki?

- ¿A quién?

-A las rusalki.

- Pero si aquí no las hubo nunca.

-iHombre! iQue no las hubo!

-Yo no sé, no las había.

-Iban a Kuz'mínskoje, nosotros íbamos, íbamos a donde está el centeno.

-Que no íbamos.

- Pues nosotros íbamos. Cuando siembran el rábano, pues en esa época.

-Yo no iba a ninguna parte (Самоделова 2007: 271, No 40).

\subsection{Moscú}

Al norte de Rjazán' está la región de Moscú. En 1973, en L’jápovo (distrito Solnečnogórskij, región de Moscú), M. E. Apráksina (nacida en 1910) contó a V. B. Sorokin la siguiente bylička, en la que también se atestigua la creencia en el hábitat acuático de las rusalki: "Un cazador viejecito solía ver a las rusalki. Llovió, las rusalki salieron del estanque, baten palmas, el cabello hasta las rodillas” (Ведерникова - Самоделова 1998: 297, núm. 147, 2, у рр. 349-50).

\subsection{Vladímir}

En la decoración exterior de la llamada casa de Prišlecov, construida en 1915 (territorio de Gorochovec, región de Vladímir, al este de Moscú), puede observarse, tallada en madera, una mujer con cola de pez (Molina Moreno 2012: 12, imagen núm. 6). Esa imagen nos hace recordar a las rusalki descritas por algunos informantes del Poles'e (vid. nuestro apartado 3.1.). Es muy curioso que los testimonios visuales de esa clase de rusalki se hallen tan lejos de las regiones en las que se atestigua la misma imagen en la tradición oral, y que, en la medida de lo que sabemos, la tradición oral de la región de

13 Klávdija Alekséevna Polikúšina interpela a una vecina, María I. Ésina. "Maša” es el diminutivo de "María". 
Vladímir no mencione a esas rusalki con cola de pez (salvo en Зеленин 1916: 217 de la edición de 1995).

Distinto es lo que vemos, por ejemplo, en una entrevista entre V. S. Próchorova (una mujer nacida en 1915, del pueblo de Čičérovo, en el territorio de Gorochovec, región de Vladímir) y L. V. Fadéeva, una investigadora del Centro de Folklore Ruso de Moscú. Dicha entrevista tuvo lugar en junio de 2001:

V. S. Próchorova: -Pues bueno, conque iríamos al molino. Y una vez dice: “Yo...”. ¿Cómo las llaman? "Kasatki”...

L. V. Fadéeva: -¿Cómo las llamaban exactamente, con qué palabra?

V. S. P.: -Cómo, dice, esto... cantaba. Cantaba, dice. He olvidado cómo la llaman. Mira: que fue al molino, y que ella todo el rato va hacia él. Mírala, parece que la estoy viendo. Mira, que he olvidado cómo la llaman.

L. V. F.: - ¿Se le apareció?

V. S. P.: - No. Solo la oyó. Solo de palabra. No podía acercarse más. Dice: "Yo me acerco, me acerco, y ella se aparta otra vez de mí. Y canta a varias voces. Una voz - dice - así de fina, fina”. Eso nos lo contaba él, mi abuelo. El padre de mi padre.

L. V. F.: - Pero ¿̇la veía?

V. S. P.: -No la veía, no la veía. iUh! No dice que la viera. Porque entre nosotros no se puede mentir. No la veía, no la veía. Pero lo que es la voz, eso, dice, lo oía. iAh! Yo, dice, todo el rato quería ver que se acercaba.

L. V. F.: -Y no le tenía miedo, ¿no?

V. S. P.: -Un poco. No sé, no sé. Solo dice: "No, yo no tenía miedo". Y ¿por qué tener miedo?, dice. Lo que tenga que ser será.

L. V. F.: -¿Puede llevarse a la gente al bosque?

V. S. P.: -No, hijita, yo no tenía miedo. Ella... "Yo no tenía miedo", dice. Dice: “Tenía quien me salvara”. iCuántos son ustedes aquí! - dice-. Este es mi nietecito. Tenía quien me salvara, dice. Y yo no tenía miedo. Es una rusalka.

L. V. F.: -¿Y él la veía en el bosque? ¿Sí? ¿O en el agua, así y todo?

V. S. P.: - En el agua la veía, sí. Un sonido, sí.

L. V. F.: -Un sonido. ¿Y eso era en el agua, así y todo?

V. S. P.: -Un sonido en el agua. Y mira, cuando íbamos al molino, mira: "Me la encuentro en un sitio" - dijo-. "Cuando entramos en ese sitio - dice- lo veo todo" (Котельникова 2004: 472, núm. 809, у р. 588).

A pesar de la manera de expresarse de la informante, bastante confusa y fragmentaria, la entrevista atestigua que la creencia en el hábitat acuático de las rusalki se mantenía viva en la región de Vladímir en 2001. También es muy interesante que la rusalka fuera invisible y se manifestara en forma acústica, como un canto a varias voces, con una voz muy fina (estos detalles, por lo visto, no resultaban contradictorios para los informantes). 
En otra zona de la región de Vladímir, el llamado territorio de Múrom, también se recogieron, en los primeros años de nuestro siglo, relatos sobre las rusalki, de los que elegimos el siguiente, en el que también hallamos a una rusalka en un medio acuático. La informante fue A. I. Novožílova, nacida en 1938 en Savančakovo; la entrevista fue realizada por S. V. Prosina y N. E. Kotél'nikova, del Centro de Folklore Ruso (Moscú), y tuvo lugar en un pueblo llamado Petrakovo, en 2003:

A. I. Novožílova: - Pues a una rusalka yo misma la vi varias veces. Allí, en mi pueblo, en Savančakovo, donde yo vivía, teníamos la casa justo al final del pueblo, y no lejos de nuestra casa había un estanque. Bueno, pues yo volvía de paseo, mi madre me cerrará la puerta, pero me dejará el ventanuco abierto, yo me metía por el ventanuco. Y una vez, no había hecho más que meterme por el ventanuco, bueno, y miré por el ventanuco, y en la orilla está sentada, desnuda, desnuda, así mismo, la mujer de la que hablo, y sus cabellos sueltos. Yo me asusté un poco, cerré el ventanuco, vale. Al día siguiente fuimos de paseo. Digo: "Chicos, venid, acompañadme a casa". "Pues ¿qqué pasa?" Yo digo: "Pues mira, tal y tal". "Venga -dicen-, vamos a ver qué pasa”. Bueno, pues nos pusimos al acecho. Y salió agarrándose, la rusalka esta, y ahí está sentada en la orilla. Y estaba toda desnuda, ahí mismo se deja caer desde la orilla, y sus cabellos sueltos, ahí mismo. Bueno, pues hete aquí que los chicos están mirando, y ella que los llama: "Venid, venid, venid". Yo digo: "No vayáis, mirad que os agarra y va y os ahoga -les digo-, no vayáis”. Eso pasó, pasó.

S. V. Prosina - N. E. Kotél'nikova: -Y ella ¿qué aspecto tenía? ¿Era joven?

A. I. N.: -Suelen ser exactamente como una mujer, como una mujer. Sí, joven, solo que estaba desnuda, no vestida. Empezaron a prepararse para echarle mano, ella salta al agua, y ya no se la puede ver. Y después ya adónde han ido a parar, las rusalki estas, no sé.

S. V. P. - N. E. K.: -Y ¿̇las llamaban así, rusalki?

A. I. N.: -Así las llamaban, rusalki.

S. V. P. - N. E. K.: -Y los vejetes ¿no le dijeron nada de eso?

A. I. N.: -No. Eso lo vi yo misma. Ya ve, yo tenía miedo y después ya le digo a mi madre: "Tú ya ábreme la puerta, para que no me meta por el ventanuco, que, si no -le digo- me agarra aquí mismo por las piernas" (Котельникова 2008: 463-4, núm. 5, y 476, n. 5).

\subsection{Jaroslavl'}

Al norte de Vladímir, en la región de Jaroslavl', E. A. Samodelova anotó en 1999 un interesante testimonio no solo de la creencia en las rusalki como criaturas acuáticas, sino de la actitud de la gente hacia esa creencia: 
Pues la rusalka... Aquí no había rusalki. Mi madre nos metía miedo, que "mira, que si vais al río, hay una rusalka sentada en una piedra y con la cola desplegada”. Nunca la vimos. Da igual, vamos al río, miramos: ¿hay una rusalka sentada en la piedra? No, o sea, que podemos bañarnos. No sé en qué se la distinguía. Simplemente nos metían miedo, y ya está. Quizá alguna vez las hubo. Porque antes la gente era sensata, creía en todo. Ahora no creen en nada, no tienen temor de nada (Самоделова 2007: 274, $\mathrm{N}^{\circ}$ 50).

Además del hábitat acuático y de la alusión a la cola de la rusalka, puede observarse cómo la creencia en estos personajes se había convertido en un recurso para mantener a los niños bajo control; pero la informante niega haber visto nunca a una rusalka. Por otra parte, es muy interesante la valoración de la creencia y de la relación entre creencia en un personaje sobrenatural, por una parte, y la existencia de ese personaje: al final de su testimonio, la informante afirma que tal vez las rusalki existieron alguna vez, porque antes la gente creía en todo. Es decir: no se cree en las rusalki por haberlas visto, sino que las rusalki existían porque se creía en ellas. Y la valoración de quien creía en ellas es igualmente curiosa: tales personas eran sensatas, en opinión de la informante, que añade, condescendiente: "Ahora no creen en nada, no tienen temor de nada”.

\subsection{Kostromá}

Al este de Jaroslavl' se halla la región de Kostromá. En el pueblo de Nerónovo, en el distrito Soligáličskij de esta región, en 1922, V. I. Smirnov tomó la siguiente nota, que permanece inédita y que encontramos en el archivo del Museo Etnográfico Ruso de San Petersburgo. Al parecer, el informante fue un hombre llamado A. S. Petuchov:

Las rusalki viven en el agua. Son bellas jóvenes que se ahogaron, niños a los que sus padres maldijeron. Se las ve por la noche y por la tarde, bañándose. Se considera peligroso para las chicas ir al río y bañarse por la tarde y por la noche ${ }^{14}$.

También de 1922 es este apunte inédito de V. I. Smirnov, debido a P. P. Charitónov, de Želnovo (distrito Soligáličskij, gobierno de Kostromá): "Las 'rusalki' son chicas jóvenes que se ahogaron, que después de la puesta del sol nadan en el río" 15.

${ }_{14}$ Archivo del Museo Etnográfico Ruso (San Petersburgo), ф. 2, оп. 2, д. 38, л. 5300/72.

15 Archivo del Museo Etnográfico Ruso (San Petersburgo), ф. 2, оп. 2, д. 38, л. 5301/73. 


\subsection{Nóvgorod}

La región de Nóvgorod se halla al NO de las de Jaroslavl' y Kostromá. En un pueblo llamado Ponomarëvo, en el distrito Chólmskij de esta región de Nóvgorod, tuvo lugar una muy interesante entrevista realizada por M. N. Vlásova y V. I. Žekúlina en julio de 1987. La entrevistada fue M. A. Andréeva, de 85 años en el momento de la entrevista, y las notas fueron publicadas en 2001. Además de atestiguar el hábitat acuático de las rusalki y otros rasgos de estas criaturas, las palabras de la señora Andréeva nos interesan porque revelan un raro ejemplo de la influencia de la literatura escrita en la tradición oral:

M. A. Andréeva: - La rusalka sale a la orilla y hace cosquillas al hombre. A eso de las diez, las once, las once y media. A las doce el prodigio no ocurrirá: el gallo canta a las doce, y a esa hora ya nada, se acaban los portentos.

Y la rusalka... Dicen, mira quién la ha visto... Hasta en un librito ${ }^{16}$ lo he leído: tiene los cabellos largos hasta el talón. Y, en cuanto sale del lago, tarde... Vive en los mares. Sale del mar y hace cosquillas al hombre. iLe hace cosquillas hasta matarlo!

M. N. Vlásova y V. I. Žekúlina: -Y aquí, en su tierra, ¿̇hay rusalki?

M. A. A.: -Sí, en el agua. Las rusalki viven en el agua.

M. N. V. - V. I. Ž.: -¿En un lago, en un estanque?

M. A. A.: -Sí, en el lago... Yo no sé, en los ríos las hay, o no. Siempre hay más en los mares, iyo misma he leído un libro!

M. N. V. - V. I. Ž.: -Pero, en su tierra, no hay lo que se dice mares...

M. A. A.: -Bueno, ¿cómo decirle? Lo que es lagos, hay, tres lagos, hay, ¿cómo no? Bueno, da lo mismo, ya no son como los mares, donde, allá lejos, se llama "mar". Pero aquí hay tres lagos uno junto a otro. Y estamos rodeados de ríos (Власова - Жекулина 2001: 275, núm. 278, у р. 455).

Ya en la década de 1990, la creencia en el hábitat acuático de las rusalki se atestigua en otros textos, también anotados en la región de Nóvgorod. De ellos, el primero que vamos a presentar procede de Koteckoe, en el distrito Starorússkij:

Pues mira que, cuando éramos pequeños, nos asustaban, que sale una mujer a la orilla, que tiene el pelo negro y se lo peina. Nos asustaban, para que no fuéramos al río a bañarnos. Cada uno la llama de una manera: uno, vydra; otros, rusalka. También nos decían los abueletes que después de la lluvia no

16 También informantes de la región de Jaroslavl' aluden a "lo que está escrito en los libros", como fuente de lo que cuentan sobre las rusalki; cf., por ejemplo, Самоделова 2007: 273, núm. 49. 
puede uno ir a bañarse, que allí se está lavando una rusalka (Черепанова 1996: 56, núm. 179).

Además del hábitat acuático, podemos observar, en ese texto, una de las ocupaciones preferidas de las rusalki (peinarse), así como un fenómeno relativamente frecuente, relativo a la pragmática del texto folklórico: a las rusalki se las menciona para asustar a los niños y mantenerlos bajo control. De ese modo, nuestros personajes desempeñan una función análoga a la del coco, el bu, la tía Tragantía o el tío Sacamantecas, en el folklore español (cf., entre otros, Amades 1957, y Pedrosa 2008).

En Ivánovskaja (en el mismo distrito Starorússkij de la misma región de Nóvgorod), también en 1990, anotaron esta bylička, en la que una rusalka, en un medio acuático, además de peinarse (como es habitual), actúa como mediadora entre el mundo de los vivos y el de los muertos ${ }^{17}$ :

Las rusalki, sí, ya, muchas veces lo he oído. Ahora ya no ha quedado nadie; pero antes había mucho de todo, se contaban muchas historias de todas clases. Mira por dónde a una mujer se le ahogó su hijo. No nadaba mal, no, nadaba bien, sí, y mira por dónde se ahogó. Y fue en verano, claro. Bueno, y la gente: “iEl vodjanój ${ }^{18}$ lo arrastró!”. Y luego ya, sí, había pasado mucho tiempo, y fue ella a lavar al río, y mira, y he aquí que hay una chica sentada en una roca, hermosa, desnuda, los cabellos negros, largos. Se los está peinando. Y ella (la mujer), cuando la vio, al punto se le heló el corazón. Se asustó mucho, se queda tiesa, ni siquiera respira. Le entró muchísimo miedo. $\mathrm{Y}$, cómo no, si es que era impresionante. Qué me dices, la rusalka, cuando mira a uno, ese se queda como de piedra, y así se quedará, puede que por mucho tiempo, sí. Bueno, pues así se queda ella. De pronto, la rusalka se vuelve y dice: "A tu hijo le va bien, vete a casa y no vuelvas más aquí". Y saltó al agua y dejó el peine en la roca. La mujer, entonces, volvió en sí, echó a correr a su casa, estuvo rezando mucho tiempo, mucho. Mucho tiempo estuvo viéndolo todo en sueños, luego ya pasó. Y el cuerpo de su hijo, pues no lo encontraron, estaba muy hondo. ¿Y quiénes son? Y quién sabe. En nuestra tierra a veces dicen que son chicas que murieron antes de su propia boda. Están penando toda su vida y no dejan vivir a la gente (Черепанова 1996: 55, núm. 172).

${ }_{17}$ Es una función propia no solo de las rusalki, sino también de otros personajes de la nečístaja sila. Por ejemplo, sobre la relación del léšij (espíritu del bosque) con el más allá, vid. Левкиевская 2004: 105; sobre su capacidad profética, vid. Криничная 2004: 319-23.

18 El vodjanój, en el folklore eslavo oriental, es un espíritu masculino de las aguas (cf. Левкиевская - Усачева 1995). 


\subsection{Carelia}

La ciudad de Petrozavodsk se halla en la república de Carelia, que a su vez está separada de Nóvgorod por la región de Leningrad. Fue en Petrozavodsk donde N. Nóvikov anotó un texto que fue publicado por V. Čistov en 1938. El informante fue un obrero jubilado, pensionista, llamado Filip Fëdorovič Gospodarëv, de 73 años. Traducimos sus palabras:

\section{QUIÉN CANTA CANCIONES Y CUENTA CUENTOS}

Las canciones y los cuentos los componen las gitanillas del mar, una especie de "rusalki". Están en el mar y cantan canciones y cuentan cuentos. Por eso, sin una chica, no se canta una canción ni se cuenta un cuento.

Y la gente, que es así de especial, se sienta a la orilla y escucha y anota qué motivo es el de la canción, y qué canción y qué cuento, lo anotan y divulgan por el mundo lo que han escrito. Y así uno lee, otro escucha, este se lo transmite a otro, y el otro a un tercero, y el tercero al cuarto...

Así siguen su camino, como decimos ahora: tenemos una sotana, se la desabrochan, y cubre el mundo por todas partes, de un extremo a otro; vayas donde vayas, allí la encuentras (Чистов 1938: 79).

Nos hallamos ante una versión bastante "evemerizada" de ciertos relatos populares ucranianos sobre cómo las "gentes marinas" son quienes inventan las melodías que luego cantamos los humanos. El más antiguo de dichos relatos fue publicado en 1846; en 1893 apareció el primero en el que, en lugar de esas "gentes marinas", el papel de modelo de la música humana lo desempeñan las rusalki, y todo ello reaparece en textos anotados en las expediciones de N. I. Tolstój en la década de 1980, en la actual Bielorrusia, como vimos en nuestro apartado 3.1. Sorprende el carácter aislado del texto de 1938, único testimonio que conocemos hasta ahora de ese motivo en una zona tan lejana de Bielorrusia como Carelia. Hay que observar que aquí el carácter mitológico de los personajes queda muy difuminado: el papel de las rusalki se ve reducido al de término de comparación de unas "gitanillas del mar".

\subsection{Archángel'sk}

Al este de Carelia, en la región de Archángel'sk, más concretamente en el distrito Belomórskij, fue anotada en 1988 una inquietante bylička que cuenta cómo una rusalka salió de un boquete abierto en el hielo, en invierno (lo cual no es nada habitual), y entonó un canto con el que profetizaba desgracias inminentes: 
En Vórenža se ahogaban muchos niños junto al puente, y una, que era una rusalka, salía de un boquete abierto en el hielo. La veían en invierno, vestida de blanco. Cantaba: "Este año es peor que el pasado" y siempre hacía una inclinación, y en verano se ahogaban muchos niños” (Черепанова 1996: 56, núm. 180).

\subsection{Siberia}

$\mathrm{Y}$, para concluir provisionalmente nuestro recorrido por el territorio eslavo oriental, debemos decir que la creencia en el hábitat acuático de las rusalki se registra también entre la población rusa de Siberia. En 1976, en Kangil (distrito Nerčínskij, región de Čitá, actual territorio de Zabajkal'sk, Siberia oriental), F. F. Belomestnova, nacida en 1907, contó a las investigadoras E. Antúf'eva y L. Petelina la siguiente bylička:

Pues he aquí que íbamos por cerezas. Estuvimos cogiendo y cogiendo y decidimos hacer un descanso en el bosque mismo. Empezamos a asustarnos unos a otros con las rusalki y los vodjanýe. $\mathrm{Y}$ de pronto vemos como una balsa que flota; pero como si no fuera una balsa. Y en esa balsa van remando y cantan canciones. Nos fijamos y vimos a unas mujeres, todas de blanco. Y peinan sus largos cabellos con peines, y ya se ponen a cantar una canción, ya ise echan a reír! Empezaron a acercarse un poco más: en lugar de piernas, tienen colas de pez. Con ellas chapotean en el agua, y a su alrededor vuelan gotas de plata. Y después, de pronto, no quedó nadie (Зиновьев 1987: 51, núm. 66, y p. 331).

En ese texto, no se especifica que esas mujeres vestidas de blanco fueran rusalki; pero presentan rasgos que otros textos, en otras regiones, atribuyen explícitamente a las rusalki: el hecho de que canten y peinen sus largos cabellos, así como la misma indumentaria y el hábitat acuático (Molina Moreno 2012: 26-7, 32, 34, 44-5, 47, 56, acerca de los vestidos blancos; 47-8, acerca del peinado; 49-62, acerca del canto).

Lo mismo podemos decir de la siguiente bylička, también anotada en Siberia oriental:

Entonces éramos niños todavía. Estábamos sentados en la orilla. Ya estaba oscuro. Y mira por dónde por aquel lado del río va una chica y va cantando. Después oímos un chapoteo, y ella viene nadando hacia esta orilla. Salió del agua, toda negra. Se sentó en una roca, soltó sus largos cabellos y venga a peinarse. Y canta. Se peinó, glu-glú, al agua... y se fue (Зиновьев 1987: 52, núm. 69, y p. 332). 


\section{CONCLUSIONES}

A la vista de los textos que hemos presentado y traducido al español, hemos podido observar que las rusalki, en la tradición oral actual de los eslavos orientales, siguen sin ser exclusivamente ninfas de las aguas. Aunque la creencia en el hábitat acuático de las rusalki sigue atestiguándose en muchas regiones de Ucrania, Bielorrusia y Rusia, también hay testimonios que presentan a nuestros personajes en el bosque y en el campo (ámbitos en los que también se hallaban las ninfas de la mitología clásica). Pero el factor diferencial entre las rusalki y las ninfas de la Antigüedad sigue consistiendo en que el hábitat de las rusalki puede variar (de los espacios acuáticos a los prados y bosques) según la época del año e incluso las horas del día. Hemos visto cómo la creencia en esa alternancia, a la que ya aludía Snegirëv en 1839, persiste sobre todo en el Poles'e; también se halla en Kubán' y en la región de Rjazán', y es uno de los rasgos que siguen distinguiendo a nuestras protagonistas con respecto a las ninfas. Entre estas últimas, puede hablarse de una especialización: hay ninfas acuáticas (náyades, nereidas, etc.), ninfas de los árboles (dríades o hamadríades), de las montañas (oréades), etc. ${ }^{19}$, y cada una se mantiene en su hábitat a lo largo de toda su vida.

Esas diferencias entre rusalki y ninfas, ya atestiguadas en el siglo XIX y conservadas en nuestros días, siguen sugiriendo que las rusalki son un producto de la imaginación de los pueblos eslavos, más que un préstamo tomado de la mitología clásica. Las afinidades entre las rusalki y las ninfas en las que creyeron los antiguos griegos y romanos pueden obedecer a un modelo indoeuropeo común, desarrollado de manera diferente entre griegos y romanos, por una parte, y eslavos orientales, por otra. ¿Puede hablarse, entonces, de un paralelismo entre las creencias de los eslavos orientales y las de la antigua Grecia? Quizá, más que como líneas paralelas, convenga describir el fenómeno en forma de líneas onduladas que se aproximan y se alejan alternativamente unas de otras. Así lo sugerían ya los testimonios del siglo XIX, y parece que los recogidos en nuestros días siguen permitiendo llegar a esa conclusión.

\section{OBRAS CITADAS}

Alvarado Socastro, Salustio (2003). Sobre la transliteración del ruso y de otras lenguas que se escriben con alfabeto cirílico. Madrid: Centro de Lingüística Aplicada "Atenea”.

19 Vid. los textos citados en n. 6. 
Amades, Joan (1957). "Los ogros infantiles". Revista de dialectología y tradiciones populares 13: 254-85.

Cosmas Pragensis (1120-1125). Chronica Boemorum, en Bretholz, Bertold, \& Weinberger, W., Hrsg. (1923). Die Chronik der Böhmen des Kosmas von Prag. Berlin: Weidmann (MGH, Scriptores rerum Germanicarum, Nova series, tomus II. Web. http://www.dmgh.de/de/fs1/ object/display/bsbooooo683_o0108.html?sortIndex=010\%3Ao6o\%3A 0002\%3A010\%3Aoo\%3Aoo [Última consulta: 31.01.2014].

Klinger, Witold (1947). "Słowiańskie rusałki, wiły, samodziwy itd. a tradycja grecko-rzymska”. Sprawozdania $z$ posiedzeń Polskiej Akademii Umiejętności (Kraków) 48, 8: 293-6.

—. (1949). Wschodnio-europejskie rusatki i pokrewne postaci demonologii ludowej a tradycja grecko-rzymska. Lublin-Kraków: Polskie Towarzystwo Ludoznawcze.

—. (1960). "Jeszcze o rusałkach i pokrewnych postaciach demonicznych i ich zależności od grecko-rzymskich tradycji”. Lud 45: 307-14.

Meyer, Karl Heinrich, ed. (1931). Fontes historiae religionis Slavicae. Berlin: De Gruyter.

Molina Moreno, Francisco (2012). De cómo las "rusalki" sobrevivieron al “gulag”. Web. http://pendientedemigracion.ucm.es/info/amaltea/acis/ docs/20120314_Molina_Rusalki.pdf. [Último acceso: 29.01.2014].

—. (2013). “Поющие русалки и нимфы”. Web. http://eprints.ucm.es/ 20576/1/Рус.ним.pdf [Último acceso: 29.01.2014].

Orbini, Mavro (21606). Origine degli Slavi e progresso dell'Imperio loro. Pesaro.

Pedrosa, José Manuel (2008). "Vampiros y sacamantecas: dieta blanda para comensales tímidos”, en Gerardo Fernández Juárez y José Manuel Pedrosa, ed. Antropologías del miedo. Vampiros, sacamantecas, locos, enterrados vivos y otras pesadillas de la razón. Madrid: Calambur: 1548.

Агапкина, Татьяна Алексеевна (2009). "Русальная неделя“ // Светлана Михайловна Толстая, ответственный редактор. Славянские древности. Том 4. Москва: Международные отношения: 501-3.

—. (2012). “Троица“ // Светлана Михайловна Толстая, ответственный редактор. Славянские древности. Том 5. Москва: Международные отношения: 320-5.

Арканников, Федор Фролович (1883). “Николаевская станица. Статистико-этнографическое описание“. Кубанский сборник 1: 548617. 
Афанасьев, Александр Николаевич (1865-9). Поэтические воззрения славян на природу. Москва: Издание К. Солдатенкова (репринт, Москва: Индрик, 1994).

Бежкович, Опанас Семёнович (†2004). “Передел старой жизни (Дневники 1923-1924 гг.)” // В. К. Чумаченко, “«Дело» Опанаса Бежковича”. Родная Кубань 2: 52-86.

Бондарь, Николай Иванович (1989). Полевые материалы I Кубанской интернациональной фольклорно-этнографической экспедиции. Динамика традиционной культуры ст. Николаевская Успенского района Краснодарского края (1882-1987 г2.). Краснодар: Кубанский Государственный Университет.

Ведерникова, Наталья Михайловна, и Самоделова, Елена Александровна (1998). Фольклорные сокровища Московской земли. Сказки и несказочная проза. Москва: Изд-во «Наследие».

Виноградова, Людмила Николаевна (2000). Народная демонология и мифо-ритуальная традиция славян. Москва: Индрик.

—. (2009a). "Русалии” // Светлана Михайловна Толстая, ответственный редактор. Славянские древности. Том 4. Москва: Международные отношения: 494-5.

—. (2009б). “Русалка” // Светлана Михайловна Толстая, ответственный редактор. Славянские древности. Том 4. Москва: Международные отношения: 495-501.

—. и Левкиевская, Елеnа Евгеньевна (2012). Народная демонология Полесья. Публикации текстов в записях 80-9о-х годов ХХ века. Том II. Демонологизация умерших людей. Москва: Рукописные памятники Древней Руси.

Власова, Марина Никитична, и Жекулина, Валентина Ивановна (2001). традиционный фольклор Новгородской области, Санкт-Петербург: Алетейя.

Зеленин, Дмитрий Константинович (1916). Очерки русской мифологии. Умершие неестественною смертью и русалки. Петроград: Орлов (1995. Москва: Индрик).

Зиновьев, Валерий Петрович (1974). Жанровые особенности быличек. Иркутск. Иркут. гос. ун-т им. А. А. Жданова.

—. (1987). Мифологические рассказы русского населения Восточной Сибири. Новосибирск: Издательство «Наука» (Сибирское отделение).

Карнаухова, Ирина Валерьановна (1928). “Суеверия и бывальщины” // Крестьянское искусство СССР. Сборник секции крестьянского 
искусства комитета социологического изучения искусств. Искусство Севера. II. Ленинград: «Асаdemia»: 77-97.

Котельникова, Наталья Евгеньевна (2004). “Былички” // Анатолий Николаевич Иванов и Анатолий Степанович Каргин, составители, Традиционная культура Гороховецккого края, том II. Москва: Государственный Республиканский Центр Русского Фольклора: 47189.

—. (2008). “Мифологическая проза" // Анатолий Степанович Каргин, автор проекта и составитель, Традиционная культура Муромского края, том I. Москва: Государственный Республиканский Центр Русского Фольклора: 457-78.

Криничная, Неонила (2004). Русская мифология. Мир образов Фольклора. Москва: Академический Проект; Гаудеамус.

Левкиевская, Елена Евгеньевна (2004). “Леший” // Светлана Михайловна Толстая, ответственный редактор. Славянские древности. Том 3. Москва: Международные отношения: 104-9.

-. (2008). “Быличка как речевой жанр” // «Кирпичики». Фольклористика и культурная антропология сегодня. Москва: РГГУ: 341-63. Web. http://www.ruthenia.ru/folklore/levkievskaya5.htm. [Último acceso: 22.06.2014].

—. и Усачева, Валерия Васильевна (1995). “Водяной” // Никита Ильич Толстой, редактор. Славянские древности. Том 1. Москва: Международные отношения: 396-400.

Лопатин, Геннадий Исаакович (2007). “'Расскажу табе пра русалак' (Представления о русалках по современным белорусским свидетельствам)”. Palaeoslavica XV/1: 275-92.

Мауроурбин (1722). Книга историография початия имени, славы, и разширения народа славянского. Санкт-Петербург: СанктПетербургская типография.

Попов, Михаил Иванович (1768). Описаніе древняго славенскаго языческаго баснословія. Санкт-Петербург: Типография сухопутного кадетского корпуса.

Пухова, Татьяна Фёдоровна (2008). Былички и бывальщины Воронежского края. Воронеж: ВГУ.

Самоделова, Елена Александровна (2007). "Русалки в Центральной России”. Palaeoslavica, XV/1: 260-74.

Снегирёв, Иван Михайлович (1839). Русские простонародные праздники и суеверные обряды, IV. Москва: Университетское Издательство. 
Татищев, Василий Никитич (1768). История Российская с самых древнейших времен. Книга первая, часть первая. Москва: Императорский Московский Университет.

Черепанова, Ольга Александровна (1996). Мифологические рассказы и легенды Русского Севера. Санкт-Петербург: Изд-во С.Петербург. ун-та.

Чистов, Василий Васильевич (1938). О собирании устного народного творчества (Руководство для собирателя). Петрозаводск: Издание Карельского научно-исследовательского института культуры. 